\title{
Faith-based action and urban regeneration
}

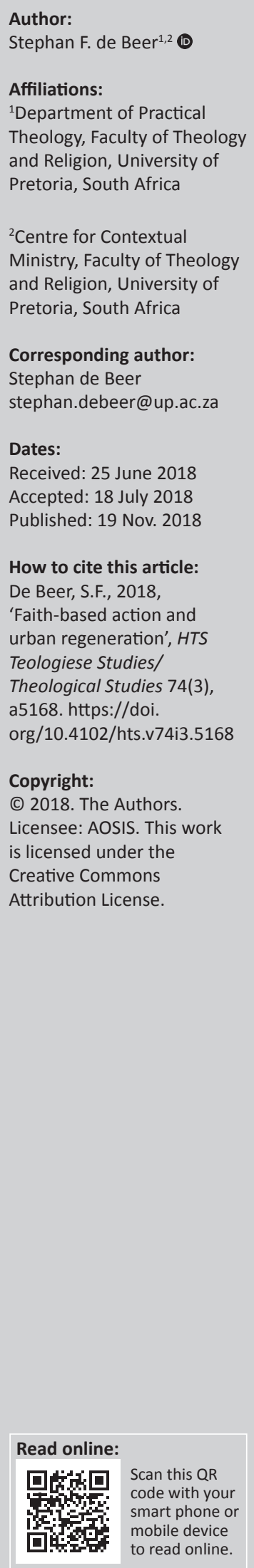

After describing the challenges, myths, exclusions and opportunities of urban regeneration, this article explores the potential interface between faith-based action and different forms of urban regeneration. Focusing on different South African cities, it considers how faith-based action could participate in regenerative urban work. Faith-based action will refer to the varied responses of churches and faith-based organisations to urban challenges and transitions. It interrogates whether faith-based action only represents many similar approaches that address urban problems superficially without mediating long-term, systemic change, or whether it indeed contributes to urban transformation in the sense of radical inclusivity and sociostructural spatial justice. Finally, it considers socio-theological sources that could potentially ground urban faith-based action theologically - such as an urban spirituality, an understanding of regeneration as integral liberation and mobilising socio-spiritual capital - whilst making a distinctive contribution to the processes of socially inclusive urban regeneration.

\section{Introduction}

This article explores the interface between faith-based action and different forms of urban regeneration. Focusing on different South African cities, I will describe the challenges, myths, exclusions and/or opportunities of urban regeneration and how specific faith-based actions seek to respond to or participate in regenerative urban work.

Faith-based action will refer to the many and varied faith-based responses to urban challenges and transitions, in particular the kind of responses aimed at healing societal fractures; engaging urban poverty, injustices or exclusion; or participating in deepening citizenship or participatory democracy in South Africa's unfolding urban landscapes.

I ask whether faith-based action only represents another in a plethora of actions that seek to salvage urban problems rather superficially without deeper long-term or systemic change, or whether it indeed finds ways to contribute to longer term urban transformation in the sense of more radical inclusivity and socio-structural spatial justice. I am interested in the socio-theological sources or values, informing faith-based actions, and propose a way of grounding urban faithbased action theologically.

\section{The ambiguity of urban regeneration in South Africa today: Challenges, myths, exclusions and/or opportunities}

\section{Urban regeneration: Concepts and definitions}

'Urban regeneration' as a term is loosely used by many different people, often having very different meanings or implying very different, even contesting visions, depending on who uses the term. The ambiguity of the term is not very helpful in fostering broad-based collaborative urban actions because smaller or less resourced partners often tend to be co-opted by the dominant understanding of urban regeneration, peddled by resource-stronger partners, often being private and public sector institutions.

Urban regeneration is a deliberate process that seeks to reverse urban decay or urban degeneration. Sometimes the process of reversing urban decay or degeneration is also referred to as urban renewal, urban redevelopment, urban revitalisation, urban reconstruction or, even, urban renaissance (cf. Cortwright 2017; Green n.d.; Klemek 2011; Roberts \& Sykes 2000; Robinson, Shaw \& Davidson 2005). These terms might not all be identical in meaning, yet they are loosely similar. They all refer to a sense of upgrading what have become decaying urban areas, infusing 'life' into 'dying' neighbourhoods, or reconstructing what is broken. 
A specific expression of the processes described above is what is known as urban gentrification. Gentrification refers to a process whereby middle-class or affluent people move into an area, or invest in the renovation of deteriorating commercial areas into more trendy markets and shops, pushing up property prices, and almost always starting a process of displacing poorer residents, often people who have resided in a neighbourhood for many years (cf. Wainwright 2016). The most well-known examples in South Africa are in Cape Town in neighbourhoods such as Woodstock, Salt River or the Bo-Kaap (cf. De Villiers 2017; Hogg 2016; Joseph 2014; Kotze 2013; Pather 2018).

There is no universal definition to describe urban regeneration. Weaver (2001) defines it as follows:

Urban regeneration is the attempt to reverse that decline by both improving the physical structure, and, more importantly and elusively, the economy of those areas. In all regeneration programmes, public money is used as an attempt to pump prime private investment into an area.

In this definition, emphasis is placed on the physical and economic conditions of an urban area. I prefer the more inclusive description of urban regeneration, as proposed by Roberts (2000):

[C]omprehensive and integrated vision and action which seek to resolve urban problems and bring about a lasting improvement in the economic, physical, social and environmental condition of an area, that has been subject to change or offers opportunities for improvement. (p. 17)

Tallon (2010), in critiquing urban regeneration, speaks of the way in which urban regeneration projects are often fragmented, lacking a holistic, integrated or strategic approach. It is in this regard that Roberts (2000:17-19) insists on the necessity for urban regeneration that goes beyond urban renewal, urban development or urban revitalisation, which, in his mind, focuses solely on physical upgrading. Urban regeneration, in his proposal, speaks of a more total or complete approach with a comprehensive, integrated, strategic and long-term aim, encompassing physical, social, economic and environmental regeneration.

Urban regeneration is often used with reference to inner city or low-income neighbourhoods, city centres or depressed urban industrial areas. In a South African context, it is less used in relation to urban townships or urban informal settlements. Perhaps this illustrates how it is a term appropriated mostly by those with capital, for use in central urban areas that are more attractive for urban entrepreneurs, unlike fringe urban areas where capital investment might show less returns. If driven by capital, areas affected by urban regeneration then often tend to become rather exclusivist, even forcing low-income people out of their neighbourhoods when property prices escalate in the name of so-called regeneration.

From the perspective of this article, I propose a revisioning of urban regeneration from three perspectives: to be revisioned from a theological perspective; to be appropriated for advancing inclusive urban transformation in more marginal urban areas; and to be reimagined in terms of how it affirms, builds upon the resources and includes, very deliberately, local residents and institutions of the areas being regenerated.

In this article, I deliberately opt for urban regeneration, both as critique of urban renewal processes that are socioeconomically exclusive, favouring profit or trendiness over people or the poor, as well as opting for the use of urban regeneration as a way of employing potentially theological language to consider socially inclusive urban change. When I refer to urban regeneration, I refer to the restoration of broken urban neighbourhoods in ways that build on the resources of local community members and institutions, ensuring that visions of regeneration are birthed from within communities, instead of being imported or imposed from outside.

I offer as a possible working definition for regeneration, expanding on Roberts' (2000) definition, the following:

$[C]$ omprehensive and integrated vision and action which seek to address urban challenges in changing or deteriorating urban neighbourhoods, bringing about lasting improvement in the economic, physical, social and environmental condition of an area, through broad-based collaborative approaches, building on local assets and resources, focusing on improvement and integration without displacement, optimizing benefits for local people and institutions, and facilitating radical social inclusion. (p. 17)

\section{From above and outside versus from below and within}

Often, urban regeneration processes are driven from above, by policymakers or urban managers, and from outside, by investors, entrepreneurs or gentrifiers. These external drivers of regeneration do not always show sensitivity for the particular histories of the neighbourhood of their focus and often have little regard for local residents who have lived in particular places for generations already.

Sadly, in the South African context, there are little to no good examples of urban regeneration being led from within and from below. There might obviously be a variety of reasons for this, depending on a particular community, including a lack of leadership or self-understanding, limited agency or resources, limited knowledge and information or divisions in communities.

Against this backdrop I argue for the importance of retrieving and asserting local community agency in conceptualising, planning and implementing urban regeneration (removed for blind peer review), optimising the integration of and benefits to local community members and ensuring that local people or institutions are not being displaced. But, even more specifically, I argue for the importance of faith-based agency to be appreciated and mobilised for socially inclusive urban regeneration in local communities. In a South African context, all neighbourhoods are hosting faith communities, comprising people from the local neighbourhood, often actively involved as residents, neighbours and citizens. 


\section{Driver and partners}

The nature of urban regeneration in a particular area is to some extent dependent on the driver (lead agent or institution) and the composition of the regeneration partners. Not all urban regeneration projects are similarly led.

In cases where the public sector, such as local government (cf. Chan \& Lee 2008), leads the process, it can become rather bureaucratic or technocratic, struggling to include local communities affected by regeneration in authentic ways in planning and implementation processes.

Market- or entrepreneur-led examples, whilst investing largely into depressed urban areas and contributing to turn around areas from decay into becoming favoured destinations (cf. Biscuit Mill in Woodstock, Cape Town, or the Maboneng Precinct, Johannesburg) (cf. Burke 2016; Joseph 2014; Myambo 2017), can become the drivers of gentrification or urban displacement (of people and histories) because of priorities which do not necessarily favour local people or local histories. A specific form of entrepreneur-led urban regeneration is what is described as culture-led urban regeneration, utilising the arts and cultural expression as catalysts for change (cf. Miles \& Paddison 2005)

Lim (2012) distinguishes between urban regeneration and urban re-imaging. Reimagining refers to a process of changing the perceptions or reputation of an area, through assigning it with new functions, meaning or identity, often including improved quality in appearance, trendy markets and other creative activities (culture-led regeneration or re-imaging is common in this regard).

This could be nothing more than a facelift, creating the perception of newness, whilst what is 'new' was only accomplished through displacement of the 'old'. This is not the same as urban regeneration in the way I would advocate for it. Market- or entrepreneur-led urban regeneration often resembles something similar to Lim's urban reimagining, which does not necessarily address some of the root causes of urban decay, instead displacing such through its interventions.

Kilroy (2014) speaks of this as 'a misalignment between regenerating areas and dealing with the social problems experienced by existing residents'. Too often, such regenerative attempts are nothing but gentrification, with seriously negative consequences for poor residents. Kilroy (2014) refers to London and New York, but the same applies to urban areas anywhere when urban interventions are not departing from a commitment to secure inclusion, well-being and optimised benefits for local people, in particular those who might be poor or particularly vulnerable. Without such a prior, and on-going, commitment, which from a theological perspective would be asserted as a preferential option for the poor, run-down and socio-economically vulnerable urban areas, get replaced by trendy spots, frequented by those with means, at the expense of those who call the place home:
The reality is that as areas become gentrified, so prices rise and rising rents and house prices push the poorest households out of the areas they identify with. Londoners are not alone in experiencing negative consequences from urban renewal. New York is also learning the costs of regeneration, having the character and residents stripped from its inner city areas, which are being colonised by high street chains and Young Urban Narcissists ('Yunnies'). (Kilroy 2014)

In certain cases, special purpose vehicles (SPVs) are created to facilitate urban regeneration. These are often in the form of public-private partnerships. Two examples will suffice here. Bethlehem (2013:18-20) speaks of the enormous contribution made by SPVs such as the Johannesburg Development Agency (JDA) and City Improvement Districts (CIDs), in terms of regenerating parts of the Johannesburg inner city. The JDA (removed for blind peer review), as a vehicle for public investment, certainly contributed to invest in high-profile urban upgrades, which often contributed to new private investor confidence, triggering exciting redevelopments which include retail, housing and entertainment destinations. In how far the poorest residents of Johannesburg Central have benefited from such regeneration remains a question, as a consolidated approach to address street homelessness, for example, has not yet been found, in spite of enormous investments.

CIDs are regulatory mechanisms providing for property owners in a particular area to organise themselves into an entity able to collect a monthly special levy, over and above normal rates and taxes, 'to be used to fund private sector management of the area' (Benjamin 2013).

The property owners establish a non-profit company to collect the levies and use the funds to provide security, cleaning, marketing, greening, park management and other services that help to uplift and protect their area. (p. 20)

Whereas CIDs play an enormous role in inner-city management and improvement, contributing to safe and liveable spaces, there are also examples of CIDs using force to exclude or displace social 'problems' or vulnerable populations from the areas under their jurisdiction (removed for blind peer review). Instead of integrated urban regeneration that includes the socially vulnerable in meaningful ways, this then becomes urban renewal at the expense of some, and, in the definition of Roberts, cannot be equated to real, deep - or radical - urban regeneration, which will address local social challenges in the area where they are to be found.

Unfortunately, the examples of social entrepreneurs driving urban regeneration are rather rare. A social entrepreneurial approach to urban regeneration will ensure the revival of a depressed area in a way that combines physical, economic, social and environmental benefits, mediating good news for long-time residents of an area, and improving an area without displacing people but in ways that offer increased access to socio-economic and other opportunities. In such cases, the benefits of regeneration are firstly shared by those who lived 
in a local regenerated community before the regeneration started, and then also with a wider community of beneficiaries.

There are also examples of university-led urban regeneration. This is often emanating from the university's selfunderstanding of being an 'anchor institution' (Melhuish 2016) that could contribute, 'as part of their civic mission' (Melhuish 2016), to socially inclusive urban regeneration:

universities have access to networks of knowledge, power and finance that they should be able to pull together to develop models of inclusive urban development. (Melhuish 2016)

However, similar to market- or entrepreneur-led urban regeneration, the effects of university-led regeneration can be similarly exclusivist. Melhuish (2016) refers to the presence of Columbia University in neighbourhoods of upper Manhattan, and how their contribution to urban regeneration contributed to a sense of 'racialized gentrification and displacement through university expansion and land value uplift' (Melhuish 2016).

Melhuish (2016) argues for the importance of universities listening to their less powerful and most vulnerable neighbours when they plan expansion or development:

We see universities as catalysts for cosmopolitan urban regeneration which challenges planning norms and patterns of elite enclave development, and genuinely makes a contribution to resolving entrenched social problems linked to lack of opportunity. (Melhuish 2016)

The University of Pretoria, for example, has a presence in a number of urban communities in the City of Tshwane. It recently won a competition for its neighbourhood redevelopment plan of the Hatfield Precinct in which its main campus is situated. A neighbourhood that traditionally has not been home to particularly vulnerable populations, the effects of this redevelopment plan do not necessarily spell doom or displacement. However, on its Mamelodi Campus, bordering sprawling urban informal settlements with a few hundred thousand residents, it still remains to be seen how the University's presence as an 'anchor institution', with considerable 'access to networks of knowledge, power and finance' (Melhuish 2016), could help broker alternative and better futures, including sustainable livelihoods and decent housing, for thousands of the city's most vulnerable people (cf. Moatshe 2018). How can the University contribute to urban regeneration that is radically inclusive in that part of the city?

A few exciting examples exist of faith-based urban regeneration, where faith-based groups do not only participate in socially inclusive urban regeneration processes, or perhaps participate in or resist socially exclusive urban regeneration processes, but faith-based groups become the drivers of urban regeneration from below, or from within. ${ }^{1}$ I will return to examples of such interventions a bit later.

1.Bethel New Life in Chicago (2018) and the Abyssinian Development Corporation (n.d.) in New York City are two impressive examples of faith-based urban regeneration initiatives.
Contrary to the vision for urban regeneration proposed by Roberts (2000:17-19), many of the examples mentioned above are severely limited:

- focusing only on physical or economic upgrading of an area, or on social improvements, without making sufficiently comprehensive interventions;

- failing to foster broad-based collaborations between public sector, private sector, civil society, the faith-based sector or universities, working in isolation and in so doing perpetuating unhealthy competition or working in silos;

- facilitating short-term change without long-term sustainability; or

- creating new destinations for outsiders without improving livelihoods or sufficiently integrating local people into the vision, implementation or benefits of urban regeneration interventions.

\section{Mediating broad-based collaborations}

Implicit in my reflection is proposing, and exploring, in how far broad-based collaborations or partnerships can be envisioned and mediated (cf. Horita \& Koizumi 2009; McCarthy 2007; Romero Bogoya 2017), in order to ensure urban regeneration that is radically inclusive. I suggest the possibility of fostering the kind of collaborations that will allow diverse resources, institutional assets and epistemological orientations, to be merged into a shared imagination. What will happen when public sector, private sector, civil society, local residents, vulnerable groups and the faith-based sector all participate in authentic and robust discernment processes, reimagining a local urban neighbourhood and its regeneration?

Not without contestation of different, often competing imaginations, honest and well-facilitated processes, honouring the diverse voices and assets as equally important, could help discern a radically different and socially inclusive imagination, but also the kinds of practices and processes that could embody it, in both a viable and sustainable manner. One of the most critical aspects of such broad-based collaborative approaches is the way in which they foster deep and collective ownership and mutual accountability in a local neighbourhood.

Romero Bogoya (2017) reflects on Latin American examples of collaborative urban regeneration initiatives, providing much insight into processes unfolding in Bogotá, but also in São Paulo, Buenos Aires and other Latin American cities. The following extract from Romero's presentation emphasises the importance of arenas for participatory interaction, depth of accountability, firm leadership and an in-depth knowledge of contextual realities as important prerequisites for a collaborative urban regeneration approach:

Collaboration emerges when the majority of the legitimate actors of the project (i.e. Market, Government, Community), establish a series of arenas of interaction, in which the interests of the different parties can be discussed and veto power is shared among the stakeholders. In order for collaboration to be initiated and executed, a firm leadership is needed, in order to safeguard 
the general objectives of the project. Furthermore, a clear awareness of the specific context is necessary in order to take advantage of the positive externalities that it may offer, as well as to tackle the threats that might be latent in it. (Romero Bogoya 2017)

\section{Revisioning (urban) regeneration as a theological category: Exploring its depths}

In reflecting on urban regeneration, theologically, we have to first retrieve ways in which the term 'regeneration' has been understood theologically. Once we have a clarified sense of a possible theological meaning of regeneration, we can bring that into critical-constructive conversation with what is construed as urban regeneration, realising of course that there is no single understanding of the term. This might help us discern, and indeed revision, urban regeneration as a theological category, which might also help in a substantial deepening of the regeneration discourse.

Regeneration, in its deepest theological sense, holds a tension between the cross and resurrection; between dying to the old and being risen to the new. Dissolving this tension or paradox is problematic, as it dissolves the core of the gospel dialectic between the cross and resurrection, between Jesus's incarnation into suffering and the hope of transformation seated in the risen Christ. Faith communities being stuck only on the cross can easily be swallowed in an urban pessimism. On the other hand, those faith communities denying the reality of suffering as part of the human condition can easily succumb to urban escapism.

Regeneration, in urban terms, cannot be facilitated based on either pessimism or escapism, but requires an urban spirituality that holds the tension between suffering and decay, on the one hand, and hopeful imagination, on the other.

Elsewhere, I sought to connect a theological understanding of regeneration with a perspective on urban regeneration, embracing the complementary thrusts of both resistance unmasking, naming and disarming death-dealing urban forces - and reconstruction, deliberately and continuously erecting or affirming signs of life (removed for blind peer review). This is based on a theological understanding of regeneration, incarnated in the dual moments of Jesus' death and resurrection, but becoming trademarks too of a certain form of Christian urban spirituality.

Nixon (2014), in an attempt to develop a theology of urban regeneration, retrieves stories from Devonport in the United Kingdom, bringing theological languages of regeneration such as death, resurrection, sin and redemption into conversation with human creation and the unfolding of (post)modern urban communities.
Green (n.d.) describes how regeneration 'has re-entered the urban vocabulary with a wide and none-too-clear meaning'. He says:

It is used to refer not only to the refurbishment of older properties and settlements but also to the intended 'renaissance' of areas even where no buildings have existed before. The building of houses, retail and commercial centres and transport hubs has attracted vast sums of international finance and highly paid consultants. No longer is land understood as opportunity to enhance human flourishing but simply as a chance to make very big returns on financial investment. Ethical issues abound - not least ecological and sociological - and theologians attempt to focus on what it could be to build community where every human being finds respect, fulfilment and God. (Romero Bogoya 2017:xxviii-xxix)

The language used can indeed be ambiguous or none-tooclear. Elwell (1997) refers to regeneration as 'new birth' and describes the nature of the implied changes as consisting 'in the implanting of a new principle or disposition in the soul'. If 'new birth' is meant here as a dissolution of suffering through displacement of those who suffer, referring to the kind of renewal that changes facades without transforming the root causes of urban decay, then it cannot be referred to as 'new birth'. But, if Elwell meant by this a truly new 'disposition in the soul' of the city, it will be a disposition that values people over profit, social and human flourishing over mere physical advancement, radical inclusion over displacement in favour of artificial change and the creation of life-affirming soul spaces taking people and places seriously. Such an understanding of regeneration will go much deeper than the popularised forms of urban renewal that too often displace the poor, and, indeed, do not implant 'a new principle of disposition in the soul' of the city, but perpetuate the neoliberal capitalist logics of profit over people and unbridled expansion or development without always considering the human, social or environmental cost.

In my proposed concept of urban regeneration, theologically remixed, I draw from an understanding of 'integral liberation' as proposed by Gutierrez (1988), but add a missing dimension, retrieving from the work of Boff (1995). Gutierrez (1988:xxxviii) describes integral liberation in terms of three forms of freedom, namely liberation from sin (spiritual freedom), personal liberation from 'every kind of servitude' (humanisation) and liberation 'from social situations of oppression and marginalisation' (socio-economic political freedom). If urban regeneration fails to contribute towards a profound sense of humanisation and socio-economic political freedom, I submit that it should go by another name and not be called 'regeneration'. If it fails, namely, to arrest deathdealing forces that dehumanise people and communities in a particular neighbourhood, it is not truly regenerative.

I would like to add the spatial dimension to Gutierrez's third dimension of liberation, imagining and working towards socio-economic spatial and political freedom. Spatial freedom would imply spatial justice translated into optimal access for all people to the resources of the city and full participation of local inhabitants of urban spaces in shaping their own local (spatial) futures. 
Boff (1995) adds a fourth dimension to integral freedom in Cry of the Earth, Cry of the Poor, writing of the close resemblance and interconnectedness between the oppression faced by the poor and the earth. A fourth dimension to be considered when assessing the impacts of urban regeneration would indeed be the environmental impacts of interventions made. Someone like Father Benigno Beltran in Manila has done considerable work over more than 35 years, journeying with a community of 30000 garbage dwellers, to ensure the transformation of the garbage dump into a proper neighbourhood with radically inclusive housing, economic opportunity and environmental recovery.

The story of Smokey Mountain has been recorded in his book, Faith and Struggle on Smokey Mountain (Beltran 2012), but it continues to unfold in remarkable ways. Without integrating a consuming passion for the protection of the earth into our liberating praxis, our regenerative processes in cities probably continue to produce toxic urban space, selfdestructive over time.

Urban regeneration, reinterpreted through a theological sense, would indeed need to be considered from the perspective of how it mediates, or not, different kinds of freedom, as referred to by Gutierrez and Boff.

In making the connection, theologically, between regeneration and society, I further find it helpful to consider a vision of urban regeneration in (South) African cities against the broader vision of Africa's regeneration as outlined in the article, 'Native Union', published by Pixley ka Isaka Seme in 1911 (Karis \& Carter 1972). Boesak (2005:64-66) describes Seme's vision in a very sensitive manner. Seme (1911) envisioned the regeneration, or reawakening, of Africa and its people, and described it as an 'entrance into a new life', or, 'a new civilisation', which will be 'thoroughly spiritual and humanistic' (cf. Boesak 2005:65). Seme's use of the term 'humanistic' should not be confused however with a Western notion wherein human agency is at the centre of secularity. In contrast, in Seme, 'humanistic' refers to the creation of a society, regenerated in a way that is humane, 'thoroughly rooted in community, in the rich African concept $u b u n t u^{\prime}$ (Boesak 2005:66). Seme roots his vision of Africa's regeneration in a spirituality that he describes as 'a common duty to perform both towards God and towards one another' (Seme 1911; quoted in Boesak 2005:66).

Very little evidence is seen in most urban regeneration projects, however exciting or trendy they might be, of such 'a new civilisation' that is 'thoroughly spiritual and humanistic'. The kind of urban regeneration that would be able to mediate multiple freedoms can only do so if rooted in a spirituality rooted in community and a common vocation of service towards God and all people. It is worth considering Seme's vision when reflecting on a radically alternative and theological vision of urban regeneration. It would envision an urban society characterised by human flourishing, integral liberation, an affirmation of mutual interdependence and deep expressions of shalom.

\section{Faith-based action and urban regeneration}

Having drawn lines between a theological understanding of regeneration and the language of urban regeneration, I would now dare to consider faith-based action (theologically informed) and urban regeneration.

'Faith' in urban regeneration (Farnell et al. 2003) offers a very important reflection on the role of faith-based organisations in urban regeneration processes. It considers the politics of religious involvement in urban regeneration; theological or value-based motivations for faith-based involvement in urban regeneration; and good or bad practices in faith communities' participation. It also makes recommendations to urban policymakers for possible ways in which to involve religion- or faith-based agency in urban regeneration processes.

The point of departure of this publication is that 'faith groups are already important in the regeneration of communities, and are often more committed and have long-term involvement' (Farnell et al. 2003). And yet, it also describes the limited understanding among urban policymakers, generally speaking, about the nature and diversity of faith communities, their existing contribution to urban well-being or regeneration, as well as possible roles they could play. Faith communities would do well to school themselves better in urban planning and policy processes, in order to participate in urban regeneration processes as equal partners, not naively so, but well informed and robustly. At the same time, urban policymakers and planners would do well to school themselves in the existing and widespread role being played by faith communities in local urban areas, often being the only institutions left in particularly vulnerable urban neighbourhoods plagued by disinvestment and systemic exclusion. The assets of faith communities need to be acknowledged and invited to contribute to integrated and long-term urban change, from below and from within.

Davey and Graham (2011:121) not only speak of the importance of faith-based engagement with cities and urban regeneration but also lament the exclusive and divisive nature of urban regeneration processes and the lack of preparedness on the part of the faith-based sector to participate in an informed and constructive manner as equal, yet critical-prophetic partners:

Urban regeneration has proven exacting and divisive for some communities. The experience of working in partnership has been mixed: some have found a vitality with many stakeholders around the table seeking to invigorate and rebuild neighbourhood; others have found partnerships to be uneven, and at times token, as concessions are made to a profit-led regeneration industry ... Despite their own transnationalism, however, faith communities have often seemed ill-equipped to tackle the global nature of the regeneration industry. Major inward investment has often come from interests with little regard for local impact, remodelling space and markets on a globalized template. (Davey \& Graham 2011:121) 
TABLE 1: Four Generations of Development.

\begin{tabular}{lllll}
\hline Variable & First Generation & Second Generation & Third Generation & Fourth Generation \\
\hline Focus & Relief \& welfare & Community development & Human right \& policy changes & Integrated local, social \& global movements \\
Problem & Shortage & Infrastructure & Institutional \& policy constraints & Inadequate vision, institutional capacity \& social contract \\
Scope & Individual / family & Neighbourhood & City-wide, region, national & National \& global \\
Time frame & Immediate short-term & Medium-term & $10-20$ years & Indefinite future \\
Facilitating role & Service provider & Mobilizer & Catalyst & Activist/educator \\
\hline
\end{tabular}

Source: Adapted from Korten, D.C., 1990, Getting to the 21st century - Voluntary action and the global agenda, Kumarian Press, Sterling, VA

Davey and Graham (2011:121), calling for faith-based engagement in urban regeneration from below, also advise caution, however, describing ways in which the faith-based (and broader non-profit) sectors often collude with exclusivist forms of urban regeneration, in the name of collaboration, in their 'scramble for influence and status, or contracts and grants' (Davey \& Graham 2011:121).

They reflect on how churches and theologians, in the United Kingdom as well as in most of the world, only now start to participate in asking 'Who is the city for?', and once this question is asked, 'questions of power, participation and the nature of citizenship are still crucial' (Davey \& Graham 2011:121). Important work in this regard was conducted by the William Temple Foundation (2018a), which devotes an entire research focus to religion and urban change, which includes critical engagement with ideas such as urban regeneration and the ways urbanity is shaped in the 21st century, as well as the engagement or apathy of religion from urban public discourse or shaping urban spaces.

\section{Faith-based action, urban regeneration and Korten's four generations}

Having considered the above cautions, caveats and challenges for faith-based action in relation to urban regeneration, I propose consideration for the four generations of development as described by development theorist, Korten (1990) (see Table 1). This could be used for both a critical assessment of local faith-based actions in relation to urban regeneration and also for encouraging faith-based actions revisited in the light of Korten's insight.

Korten (1990:117) speaks of four generations of development when he considers non-profit developmental action. Although Korten's emphasis is not necessarily urban, Korten's insight into developmental action could be of great value for re(en)visioning urban regeneration processes. He presents the four generations as a continuum of engagement, gradually shifting from only short-term, personal or local interventions or change - in the form of relief or community development - to more systemic, regional and even global changes, through advocacy and justice work, and through participation in local, regional and global social movements.

The first generation of development engages in relief work, addressing symptoms of poverty or exclusion and providing short-term support (cf. Korten 1990:115-118). Many faithbased actors in urban areas provide short-term relief in response to dire need. However, there are certain concerns. As part of an urban regeneration agenda, relief should not be discarded, nor should it be relegated as something inferior, but integrated into a more holistic and comprehensive agenda for action. The danger is for faith-based groups to allow themselves to be relegated to the function of relief, without appreciating the larger contribution it could potentially make to socially inclusive urban regeneration. Also, although relief in itself is vitally important, on its own it could avoid the kind of engagements necessary to facilitate systemic change.

Korten (1990:118-120) describes a second-generation approach to development as community development. A community development approach goes beyond relief, seeking to create essential infrastructure in partnership with local communities. The purpose is to mediate increased access to services and opportunities, to develop self-reliance and for communities to take ownership for shaping their own futures. Community development approaches generally seek to involve the larger community, going beyond short-term individual relief to facilitate, according to Korten, medium-term solutions.

In some poorer urban communities, the only work being carried out in terms of holistic community development is done by faith-based organisations or churches. As part of an urban regeneration agenda, faith-based community development initiatives could make a huge contribution. This has been evident in various cities across the world, ${ }^{2}$ although it is not universally true. Many impoverished urban communities not only lack sustained community development processes but also the visible absence of churches or faith-based communities from the issues affecting and shaping communities, often detrimentally, is glaring. In cases where faith-based actions involve community development, the lessons learnt often enable such faith-based groups to move into an expanded agenda, also embracing third- and fourthgeneration approaches to development.

Many communities have been deprived of opportunities for generations and systemically excluded from the opportunities and resources of the city. Even bold community development initiatives might not mediate optimal benefits because of structural constraints. A third-generation approach, advocated for by Korten (1990:120-123), will embark on processes that facilitate more fundamental institutional and policy changes, driven by a people-centred development agenda. A third-generation approach recognises the need for systemic change if community development is to translate into long-term transformation.

2.Examples can be found in the members of the Christian Community Development Association, working in cities and towns across the United States (2018); the work Association, working in cities and towns across the United States (2018); the work
of Ben Beltran (2012) and Veritas Inc. in Smokey Mountain, Manila; and many others scattered across cities of the globe. 
Certain policies - local or national government - hinder human and neighbourhood flourishing, and certain institutional paradigms - public or private sector, civic agencies, churches or others - work against radical forms of inclusion. This approach asks for catalysts, advocates and policymakers engaged in an overtly political manner to bring about systemic changes in relation to institutional paradigms, policies and budget allocations.

In terms of urban regeneration, this would be the place in which faith-based actors start to ask: 'Who is excluded, and, importantly, why?' Faith-based action then would integrate advocacy, lobbying and policy work into their own strategies, and its participation in urban regeneration processes would be very critical, continuously advocating for the most inclusive forms of regeneration, whilst resisting the exclusion or displacement of anyone or any group, in facilitating regeneration initiatives.

A fourth-generation approach, as described by Korten (1990:123-135) and advocated by Swart (2006), goes beyond development as relief or community development, or even development as advocacy for justice, but is an approach that finds deep solidarity with global movements of justice, seeking to facilitate larger scale societal justice in a global sense. Considering urban regeneration from such a fourthgeneration approach would entail global coalitions between urban communities sharing similar concerns and aspirations for radically inclusive urban regeneration, from within and from below. Such collaborative movements will share lessons and good practices, working towards systemic change in global urban discourses and practices. Architects, urbanists, policymakers and communities from places like Mexico City, Djakarta or Khayelitsha in Cape Town will learn from each other, influence each other and participate in global alliances to work for radical global change. An example is the collaborative work done by housing activists through formations like Habitat International Coalition (n.d.).

Services and infrastructures facilitated by faith-based action often occur in the fractured spaces of the city, with those forgotten by society. As such, services of relief or infrastructure development, even if not meant that way, become prophetic signs, both of what is wrong with society but also of what a caring society will look like. We need to be careful therefore not to view the four generations as oppositional, or the first or second generation as inferior to the third or fourth. Rather, we should use Korten's four generations as descriptive, assessing ourselves not only in terms of our own identity but also in terms of the impact we have in a local community. We should view the four generations as deeply complementary, contributing in their different emphases towards integrated development, or urban regeneration, that facilitates multiple freedoms. We should also be careful though, as faith communities, not to be stuck in one generation in ways that limit the freedoms that could be facilitated potentially, had we embraced a fuller engagement with urban challenges, in a globally connected way, and through engagement in all four generations.

\section{Retrieving and fostering socio- theological sources for assessing and realising urban regeneration}

A theological vision of urban regeneration that is characterised by human flourishing, integral liberation, an affirmation of mutual interdependence and deep expressions of shalom, as described earlier in this article, could indeed remain a lofty, even unrealistic vision if not considered in a much more concrete sense.

Much too often our deep theological convictions, values and visions exist as a mere coincidental backdrop to our deeply committed faith-based action. Seldom do we interrogate ourselves deeply enough to ascertain whether our actions indeed align to, or realise, these convictions, values and visions. We can speak of God's shalom without ever mediating concrete embodiments thereof.

Faith-based groups engaged in processes of urban regeneration need to consider two critical tasks: a framework needs to be developed for measuring the impact and possible sociotheological sources need to be retrieved and developed to help realise and optimise the impact. Both of these have to do with responsible and accountable stewardship of resources.

In terms of the first task, there is an array of evaluative tools and frameworks that were developed in recent years in social sciences and planning disciplines, both to assess the impact of urban regeneration, and, more specifically, of urban regeneration that is socially sustainable. ${ }^{3}$ Similarly, such impact assessment tools are also developed by venture capital funds, social entrepreneurs and impact entrepreneurs. ${ }^{4}$ Faith-based groups would do well to take note and learn from such tools and frameworks, whilst adapting them for their own purposes.

It is important to assert that the wheel need not be rediscovered. And yet, existing frameworks or tools can be further enhanced by adding the measurement of specific outcomes that might be unique to a faith-based urban regeneration approach and aligned to a theological vision of urban regeneration. A faith-based framework to measure urban regeneration might have to include concrete indicators that speak of the realisation of sometimes abstract-sound objectives. What will the indicators be to measure objectives such as mutual interdependence, human flourishing or the biblical concept of shalom? What indicators will demonstrate that faith-based action facilitates a deep and real sense of integral liberation: spiritual, psychological and emotional freedom; interpersonal freedom and human dignity; socioeconomic freedom; spatial freedom; environmental freedom; and political freedom?

3.Various assessment tools have been designed to assess the social, economic, physical and environmental impact of urban regeneration. For just a few examples, (2015)

4.Various assessment tools are developed to measure the impact of socia entrepreneurship or impact entrepreneurs. The works of Bertotti et al. (2011) and Grieco (2015) serve as two examples. 
Grandiose theological visions need to be translated into concrete reflective and evaluative frameworks to assist in the task of continuous, rigorous self-assessment, self-reflection, self-critique and self-correction. Such frameworks, theologically adapted and enhanced, could then help facilitate concrete and sustainable embodiments of radically alternative urban imaginaries. This article will not endeavour to propose such a framework but is advocating for its necessity.

The second task relates to the retrieval or development of socio-theological sources to help realise urban regeneration. These are sources that, upon retrieval, could assist both in realising urban regeneration in a deeper, more radical sense and also in the previous task of assessing in how far we indeed realise our theological imaginaries of urban regeneration.

Here I would only refer to three such possible resources, namely an urban spirituality; a theoretical understanding of (urban) regeneration as integral liberation and transformation; and the employment and mobilisation of socio-spiritual capital.

\section{An urban spirituality}

Faith communities might be active in local urban neighbourhoods without necessarily having a wellarticulated, or expressed, urban spirituality. When I refer to an urban spirituality, I speak of it as a spirituality combining imagination and transformation:

A spirituality of transformation is the discipline of opening ourselves up to God's Spirit, who is creating within us a new imagination; and the values, commitmen/ts, rituals and actions that will realize this imagined, yet transformed, urban reality (removed for blind peer review). (De Beer 1998:98)

In the context of this article, an urban spirituality of transformation, or regeneration, would bring to bear the critical moments of incarnation, cross, resurrection and Pentecost, on the death-dealing challenges urban people, places and systems face. It would not only make deliberate attempts to read the signs of the times, prophetically and as part of a ministry of discernment, but it will also trace signs of the Spirit at work in urban histories and narratives, both globally and locally. An urban spirituality would discern false gods dealing death and locate signs of the God of life - both in the city and in religious communities of the city. Our inability to read, discern and name death-dealing forces, and our lack of courage to do so, prevent urban regeneration of the right kind.

Such a spirituality would transform local worship experiences, allowing for 'profane' contextual challenges to infiltrate 'sacred' worship spaces. At the same time, an urban spirituality would discern signs of the 'sacred' in 'profane' urban spaces, helping us to foster a new imagination of the city that could be. Inherent to an urban spirituality is a theology of place, seeking and affirming signs of God's gracious presence everywhere.

\section{Regeneration as integral liberation and transformation}

An urban spirituality, in my mind, would foster an imagination of both liberation and transformation. Sustainable and radically inclusive forms of urban regeneration - with psychological, spiritual, social, economic, structural, spatial, environmental and political dimensions - need to be preceded by integral liberation, in the sense used by Gutierrez (1988:xxxviii). The kind of regeneration that implies and demands integral liberation would flow from a deep spirituality, or a lived faith (cf. Gutierrez 1988:xxxiii-xxxvi). This is demonstrated by faith-based responses across the globe responding from within a deeply rooted faith, present in the city, but also from a pronounced faith in the city, as a place of resource, potential and possible sustenance, which can mediate flourishing life, if managed in ways that consider all God's children with equal respect and regard.

Regeneration as integral liberation implies the mediation of all-encompassing freedom, or multiple freedoms in different spheres of life that help pave the way for truly transformed urban systems, places, relationships and people. Faith communities have the responsibility to foster a spirituality of urban transformation as a central part of the vocation of urban theologies, theological education or worshipping communities. Fostering a spirituality of urban transformation is about fostering a new consciousness that embraces the possibility of urban redemption.

\section{Socio-spiritual capital}

Faith communities, collectively, possess socio-spiritual capital $l^{5}$ which is often isolated within the narrow confines of such communities. However, it holds enormous possibilities to contribute to socially inclusive urban regeneration.

Narrow theological imaginaries disable faith communities from mobilising their own socio-spiritual capital in the interest of urban regeneration and change.

I consider five important categories which faith communities could offer as socio-spiritual capital in the process of urban regeneration: moral authority, property ownership, human resources and gifts, inherent networks and relationships, and a sense of vocation.

Faith communities still have a measure of moral authority (Prozesky 2017) in local communities, and, if organised, hold the potential to keep local governments and businesses accountable to ethical conduct. Through participation in local development processes, faith communities - often closely connected to grass-roots concerns and aspirations and sometimes well trusted - can help organise communities, create community development projects, invest in locally generated initiatives of community members or non-profit organisations and inform policymaking processes.

5.Cf. the work of Ignatius Swart on social capital and the church (2006), as well as the description of spiritual capital as proposed by the William Temple Foundation, https://williamtemplefoundation.org.uk/spiritual-capital/ 
The church and faith communities are also landlords and property owners. InaSouthAfrican context, inmosturbanneighbourhoods, churches and other religious groups own a collective property portfolio that if reimagined could contribute significantly to regeneration from below. The remodelling of church properties or buildings into multi-purpose centres addressing a range of community issues could demonstrate the kind of sociospatial spiritual transformation envisaged in a theological understanding of urban regeneration. It could offer, through its land or property, opportunities for and access to diverse types of social or affordable housing, economic opportunity, educational services, micro-finances, information, agriculture and food security, health clinics and various other forms of access serving the well-being of the community.

Its land and property can be reimagined to contribute to restorative justice post-apartheid. Interesting examples exist of North American churches pooling their property assets as equity for making large-scale socio-economic investments, not for the profit of the church but for the well-being and flourishing of local neighbourhoods and people.

Within faith communities, all the human resources and gifts required to (re)build urban communities are present. Urban regeneration from below requires diverse professional competencies and skills sets, much time and personal investment, as well as the collective imaginations of all God's people. If our urban discipleship can include an alignment of people's resources and gifts to some of the greatest urban challenges we face today, we might see replications of Jesus' multiplication of the bread and fish in many different ways in cities all over the global landscape.

Not only can the mobilisation of individual assets contribute to urban regeneration but also the inherent networks and relationships existing in Christian faith communities can help broker change-making in the direction of a more inclusive, just and sustainable city, at all levels and in all spheres of society. The challenge is for stewarding these wide-ranging networks and relationships well, weaving together a net of caring justice undergirding the urban fibre like the wings of an eagle.

I suggest vocation as another element of socio-spiritual capital that cannot easily be replaced by anything else. A deep sense of vocation is marked by unwavering commitment, a willingness to sacrifice and relentless perseverance, as it flows from a deep conviction of being held by the One who called us. Vocation has the ability to overrule other, sometimes more destructive or exclusivist, passions. In fragile urban communities, such vocation is what could provide the glue for reweaving dismembered places and systems over long periods of time.

\section{Regeneration through incarnation: A conclusion}

Theologically speaking, from a position of solidarity with vulnerable or excluded communities, regeneration that is determined by forces of market-led urbanisation, and not countered by deep incarnation, would probably always favour the few at the expense of the majority of poorer urban dwellers.

Such regeneration - which does not emerge from below or from within communities - tends to be dictated by both imaginary and concrete expressions of regeneration imposed, or imported, from outside a local community, too often even at the expense of the community originally inhabiting a space. The motif of profit then overshadows the well-being of people.

The regenerative possibilities mediated by Christ were enabled by his deep incarnational solidarity, exorcising the exclusivist ethos and practices of both temple and city alike. I conclude this article with reference to the work of veteran faith-based community activist, civil rights leader and pastor, Perkins (2007), who draws deeply from the incarnate Christ in his own understanding of Christian community development.

Perkins (2007) speaks of the 3 R's of Christian community development as relocation, reconciliation and redistribution. For Perkins the process of community development, or urban regeneration, in a theological and incarnational sense, has to start with relocation. He calls for people of faith either to hold their ground in hard urban places or to deliberately relocate into places of urban struggle, in order to work with local communities and people, in relationships of deep solidarity, for urban change and social justice.

Flowing from such an incarnational presence, with local communities of struggle, would be multiple expressions of reconciliation - racial, economic, denominational, religious, gender and generational. As incarnational relocation is deeply relational, it would continuously seek to break down walls and barriers that isolate, segregate or exclude. Instead, it would seek to build bridges that undermine every form of prejudice or exclusion. Such relationships would prevent regeneration that is exclusionary, as it would foster the kind of solidarity that would not allow neighbours, friends, indeed sisters or brothers, to be displaced.

Once such reconciling patterns are created across a local community, the possibility of more radical redistribution of resources inside and among members of the community would almost become inevitable. Now those with more will consider the use of their resources in redeemed ways, and local communities of faith will interrogate the ways in which they use their land and property for the shalom of the city. This will constitute an urban Pentecost community in the deepest sense of the word.

We can speak of different forms of urban regeneration, both critiquing those forms that are exclusive of the poor and encouraging radical expressions of socially inclusive and bottom-up regeneration. Perkins, however, provides us with the most basic and most radical model, characterised by relocation, reconciliation and redistribution. Redistribution is the side of reconciliation that demands justice. Reconciliation 
is the side of redistribution that demands mercy. They meet each other in, and flow from, unconditional incarnation. It means people and communities of faith, living their lives and holding their ground in the hardest urban places. Once incarnation, reconciliation and redistribution fuse together, the possibility of surprising forms of radical regeneration becomes real. Any other form of regeneration risks forgetting the urban poor.

\section{Acknowledgements Competing interests}

The author declares that he has no financial or personal relationships which may have inappropriately influenced him in writing this article.

\section{References}

Abyssinian Development Corporation, n.d. Believe. Build. Empower, viewed 19 May 2018, from http://www.adcorp.org/

Beltran, B., 2012, Faith and struggle on Smokey Mountain: Hope for a planet in peril, Orbis Books, Maryknoll, NY.

Bertotti, M., Leahy, G., Sheridan, K., Tobi, P. \& Renton, A., 2011, 'Measuring the impact of social enterprises', British Journal of Health Care Management 17(4), 152-156. https://doi.org/10.12968/bjhc.2011.17.4.152

Bethel New Life, 2018, Bethel New Life, viewed 19 May 2018, from http:// bethelnewlife.org/

Bethlehem, L., 2013, 'A new dynamic - Urban regeneration in the Joburg CBD', The Journal of the Helen Suzman Foundation 69, 17-24

Boesak, A.A., 2005, The tenderness of conscience: African renaissance and the spirituality of politics, Sun Press, Stellenbosch.

Boff, L., 1995, Cry of the earth, cry of the poor, Orbis Books, Maryknoll, NY.

Burke, J., 2016, “"Regeneration should be for all”: Will change in Johannesburg benefit its poorest residents?', The Guardian, 02 October 2016, viewed 18 May 2018, from https://www.theguardian.com/cities/2016/sep/26/regeneration-gentrificationjohannesburg-south-africa-change-poorest-residents-gentrification

CCDA, 2018, We inspire generations, viewed 19 May 2018, from https://ccda.org/

Chan, E.H.W \& Lee, G.K.L., 2008, 'A sustainability evaluation of government-led urban renewal projects', Journal of Facilities 26(13/14), 526-541. https://doi. org/10.1108/02632770810914280

Cortwright, J., 2017, 'Is the urban renaissance over?', CityLab, 25 May, 2017, viewed 18 May 2018, from https://www.citylab.com/equity/2017/05/is-the-urbanrenaissance-over/528135/

Davey, A. \& Graham, E., 2011, 'Inhabiting the good city: The politics of hate and the urbanisms of hope', in J. Beaumont \& C. Baker (eds.), Postsecular cities: Space, theory and practice, pp. 120-134, Bloomsbury Publishing, London.

De Beer, S., 1998, 'Towards a theology of inner city transformation. The church, housing and community in the city', unpublished DD-thesis, University of Pretoria, Pretoria.

De Villiers, J., 2017, 'They chucked me out like a dog' - Evicted Woodstock resident, News24, 01 November, 2017, viewed 18 May 2018, from https://www.news24. com/SouthAfrica/News/they-chucked-me-out-like-a-dog-evicted-woodstockresident-20171101

Elwell, W.A., 1997, Evangelical Dictionary of theology, Baker Books, Grand Rapids, MI.

Farnell, R., Furbey, R., Hills, S.S.A-H., Macey, M. \& Smith, G., 2003, 'Faith' in urban regeneration? Engaging faith communities in urban regeneration, The Policy Press, Bristol.

Glasson, J. \& Wood, G., 2009, 'Urban regeneration and impact assessment for social sustainability', Impact Assessment and Project Appraisal 27(4), 283-290.https:// sustainability', Impact Assessment and
doi.org/10.3152/146155109X480358

Green, L., n.d., Urban regeneration, viewed 15 April 2018, from http://lauriegreen. org/urban/regeneration.html

Grieco, C., 2015, Assessing social impact of social enterprises. Does one size really fit all?, Springer, Heidelberg.

Gutierrez, G., 1988, A theology of liberation: History, politics and salvation, Orbis Books, Maryknoll, NY.

Habitat International Coalition, n.d., viewed 13 May 2018, from http://www.hic-gs.org/

Hogg, C., 2016, 'Uncertain future for residents of old stables in Woodstock, Ground' GroundUp, 13 July, 2016, viewed 18 May 2018, from https://www.groundup.org. za/article/uncertain-future-residents-old-stables-woodstock/

Horita, M. \& Koizumi, H., 2009, Innovations in collaborative urban regeneration, Springer, Japan.
Joseph, R., 2014, 'The gentrification of Woodstock: From rundown suburb to hipster heaven', The Guardian, 12 August, 2014, viewed 18 May 2018, from https://www. theguardian.com/cities/2014/aug/12/gentrification-woodstock-cape-towntheguardian.com/cities/
suburb-hipster-heaven

Karis, T. \& Carter, G.M., 1972, From protest to challenge: A documentary history of African politics in South Africa, 1882-1964, Volume 1: Protest and Hope, 18821934, Hoover Institute Press, Stanford University, Stanford, CA.

Kilroy, J., 2014, 'What is the aim of urban regeneration', RTPI (Royal Town Planning Institute), 14 November, 2014, viewed 21 May 2018, from http://www.rtpi.org. $\mathrm{uk} /$ briefing-room/rtpi-blog/what-is-the-aim-of-urban-regeneration/

Klemek, C., 2011, The transatlantic collapse of urban renewal: Postwar urbanism from New York to Berlin, University of Chicago Press, Chicago, IL.

Korten, D.C., 1990, Getting to the 21st century - Voluntary action and the global agenda, Kumarian Press, Sterling, VA.

Kotze, N., 2013, 'A community in trouble? The impact of gentrification on the Bo-Kaap, Cape Town', Urbanilzziv 24(2), 124-132. https://doi.org/10.5379/urbani-izziven-2013-24-02-004

Lim, M., 2012, 'Urban regeneration and re-imaging', 14 March, 2012, viewed 08 May 2018 , from http://askmichellegeography.blogspot.com/2012/03/urban-regeneration-andre-imaging.html

McCarthy, J., 2007, Partnership, collaborative planning and urban regeneration, Ashgate Publishing, Hampshire.

Melhuish, C., 2016, 'In urban development, universities can be better neighbours', Times Higher Education, 02 April, 2016, viewed 19 May 2018, from https://www. timeshighereducation.com/blog/urban-development-universities-can-be-betterneighbours

Miles, S. \& Paddison, R., 2005, 'Introduction: The rise and rise of culture-led urban regeneration', Urban Studies 42(5/6), 833-839. https://doi.org/10.1080/ 00420980500107508

Moatshe, R., 2018, “'Dreamers” behind urban renewal', Pretoria News, 05 March 2018, viewed 18 April 2018, from https://www.iol.co.za/pretoria-news/dreamersbehind-urban-renewal-13597901

Myambo, M.T., 2017, 'In their rush to become global, hipster-friendly cities risk creating spatial apartheid', Quartz Africa, 14 May, 2017, viewed 19 May 2018 , from https://qz.com/983312/johannesburgs-maboneng-hipster-neighborhoodis-in-danger-creating-a-new-kind-of-apartheid/

Nixon, D., 2014, 'Towards a theology of urban regeneration: Stories from Devonport', International Journal of Public Theology 8(2), 223-245. https:// doi.org/10.1163/15697320-12341343

Pather, R., 2018, 'Bo-Kaap unites in protest to hold on to heritage', Mail \& Guardian 28 May, 2018, viewed 08 June 2018, from https://mg.co.za/article/2018-05-28bo-kaap-residents-take-on-city-of-cape-town

Perkins, J., 2007, With justice for all: A strategy for community development, Regal Books, Ventura, CA.

Ploegmakers, H. \& Beckers, P., 2015, 'Evaluating urban regeneration: An assessment of the effectiveness of physical regeneration initiatives on run-down industrial sites in the Netherlands', Urban Studies 52(12), 2151-2169.

Prozesky, M., 2017, 'Faith communities and our moral crisis', News24, 16 April, 2017, viewed 15 May 2018, from https://www.news24.com/Columnists/GuestColumn/ faith-communities-and-our-moral-crisis-20170414

Roberts, P., 2000, 'The evolution, definition and purpose of urban regeneration', in P. Roberts \& H. Sykes (eds.), Urban regeneration: A handbook, pp. 9-36, Sage, London.

Roberts, P. \& Sykes, H., 2000, Urban regeneration: A handbook, Sage, London.

Robinson, F., Shaw, K. \& Davidson, G., 2005, 'Regenerating places, not people', Local Economy 20(1), 13-26. https://doi.org/10.1080/0269094042000313584

Romero Bogoya, J., 2017, 'Towards collaborative approaches in urban regeneration: A case study in the Latin American context', unpublished masters-thesis, Delft University of Technology.

Seme, P., 1911, 'Native union', Imvo Zabantsundu, 24 October, 1911.

Swart, I., 2006a, The churches and the development debate: Perspectives on a fourth generation approach, Sun Press, Stellenbosch.

Swart, I., 2006b, 'Churches as a stock of social capital for promoting social development in Western Cape communities', Journal of Religion in Africa 36(3), 346-378. https://doi.org/10.1163/157006606778941913

Tallon, A., 2010, Urban regeneration in the UK, Routledge, Abingdon.

Wainwright, O., 2016, 'Gentrification is a global problem. It's time we found a better solution', The Guardian, 29 September, 2016, viewed 19 May 2018, from https:// www.theguardian.com/cities/2016/sep/29/gentrification-global-problem-bettersolution-oliver-wainwright

Weaver, M., 2001, 'Urban regeneration - The issue explained', The Guardian, 19 March, 2001, viewed 18 May 2018, from https://www.theguardian.com/ society/2001/mar/19/regeneration.urbanregeneration1

William Temple Foundation Limited, 2018a, Religion, urban change and the environment, viewed 18 April 2018, from https://williamtemplefoundation.org. uk/our-work/research/religion-urban-change-environment/

William Temple Foundation Limited, 2018b, William Temple Foundation, viewed 23 May 2018, from https://williamtemplefoundation.org.uk/spiritual-capital/ 